Estuarine, Coastal and Shelf Science

November 2015, Volume 165, Pages 52-60

http://dx.doi.org/10.1016/i.ecss.2015.09.003

http://archimer.ifremer.fr/doc/00278/38963/

(C) 2015 Elsevier Ltd. All rights reserved.

\title{
Phytoplankton versus macrophyte contribution to primary production and biogeochemical cycles of a coastal mesotidal system. A modelling approach
}

\author{
Plus Martin ${ }^{1, *}$, Auby Isabelle ${ }^{2}$, Maurer Daniele ${ }^{2}$, Trut Gilles ${ }^{2}$, Del Amo Y. ${ }^{3}$, Dumas Franck ${ }^{4}$, \\ Thouvenin Benedicte ${ }^{4}$
}

${ }^{1}$ Ifremer, DYNECO/PELAGOS, B.P. 70, 29280 Plouzané, France

2 Ifremer, LER/AR, Quai du commandant Silhouette, 33120 Arcachon, France

${ }^{3}$ Université de Bordeaux, UMR EPOC, 33615 Pessac, France

${ }^{4}$ Ifremer, DYNECO/PHYSED, B.P. 70, 29280 Plouzané, France

*Corresponding author : Martin Plus, email address : Martin.Plus@ifremer.fr

\begin{abstract}
:
This study presents an assessment of the contributions of various primary producers to the global annual production and N/P cycles of a coastal system, namely the Arcachon Bay, by means of a numerical model. This 3D model fully couples hydrodynamic with ecological processes and simulates nitrogen, silicon and phosphorus cycles as well as phytoplankton, macroalgae and seagrasses. Total annual production rates for the different components were calculated for different years $(2005,2007$ and 2009) during a time period of drastic reduction in seagrass beds since 2005 . The total demand of nitrogen and phosphorus was also calculated and discussed with regards to the riverine inputs. Moreover, this study presents the first estimation of particulate organic carbon export to the adjacent open ocean. The calculated annual net production for the Arcachon Bay (except microphytobenthos, not included in the model) ranges between 22,850 and 35,300 tons of carbon. The main producers are seagrasses in all the years considered with a contribution ranging from $56 \%$ to $81 \%$ of global production. According to our model, the $-30 \%$ reduction in seagrass bed surface between 2005 and 2007 , led to an approximate $55 \%$ reduction in seagrass production, while during the same period of time, macroalgae and phytoplankton enhanced their productions by about $+83 \%$ and $+46 \%$ respectively. Nonetheless, the phytoplankton production remains about eightfold higher than the macroalgae production. Our results also highlight the importance of remineralisation inside the Bay, since riverine inputs only fulfill at maximum $73 \%$ nitrogen and $13 \%$ phosphorus demands during the years 2005, 2007 and 2009. Calculated advection allowed a rough estimate of the organic matter export: about $10 \%$ of the total production in the bay was exported, originating mainly from the seagrass compartment, since most of the labile organic matter was remineralised inside the bay.
\end{abstract}

Keywords : Primary production, Macrophyte, phytoplankton, Biogeochemical cycle, physical-ecological coupled model, Arcachon Bay 


\section{Introduction}

The coastal zone, although representing less than $1 \%$ of the total oceanic surface, is characterized by high biodiversity and intense productivity (gross primary production ranges from 18 to $232 \mathrm{Mol} \mathrm{C}$ $\mathrm{m}^{-2} \mathrm{y}^{-1}$, according to Gattuso et al., 1998). In the shallowest areas, the primary producers are microalgae (phytoplankton, microphytobenthos), macroalgae (seaweeds) or marine phanerogams (seagrasses). These three compartments constitute the basis of coastal trophic chains although their growth kinetics, the quality of the organic matter they produce, and their impacts on biogeochemical cycling are very different. For instance, the effects of seagrass beds on early diagenesis in superficial sediments are important (Hemminga et al., 1994 ; Welsh et al., 2000 ; Jensen et al., 2005 ; Deborde et al., 2008) and this has an impact on the nutrient fluxes at the sediment-water interface, and consequently on the water column primary production as well. Moreover, the fate of seagrass detritus is different from that of macroalgae or phytoplankton. In fact, the perennial and slow growing seagrasses produce detritus rich in organic carbon and is of refractory quality. Seagrass detritus is much more inclined to be exported by currents over large distances, washed onshore or buried into the sediment. On the contrary, algal detritus is more likely to be decomposed inside the system, participating in internal nutrient regeneration (Enriquez et al., 1993).

The transition zone between land and ocean is firstly affected by variations in terrestrial inputs from natural and anthropogenic origins. Evidence of threats to coastal ecosystems by ongoing habitat degradation has been reported worldwide (Gray, 1997, and references therein). Seagrass meadows are suffering from a global decline (Waycott et al., 2009) that may lower primary productivity as well as net secondary production in the impacted ecosystems (Heck et al., 2008), enhance sediment erosion (Ganthy et al., 2014), cause change in biodiversity and in trophic structure (Duffy et al., 2005), and cause modification in the sediment redox status (Delgard et al., 2013). Thus, it seems worthwhile to study the biogeochemical cycles of a whole coastal system (lagoon, bay, estuary), including all types of primary producers, in order to understand its global functioning and give new insights to the prevailing changes. Nonetheless, as natural systems usually behave non-linearly due to complex 
interactions between biotic and abiotic processes, it is often arduous to extrapolate the processes recorded at small scales from the global functioning at regional scales. Cloern (2001) stresses the high level of variability of responses to nutrient changes that a coastal ecosystem exhibits. Ecosystem models, although aggregating ecological diversity into a small number of state variables (functional groups), can help in reproducing plausible patterns of biogeochemical cycles and in assessing the ecosystem responses to anthropogenic or natural changes (Lancelot et al., 2002 ; Zaldívar et al., 2009; Duarte et al., 2008; Azevedo et al., 2014).

The Arcachon Bay is a macro-tidal triangular-shaped lagoon (surface $174 \mathrm{~km}^{2}$, mean depth $4.6 \mathrm{~m}$, tidal amplitude ranges between 0.8 and $4.6 \mathrm{~m}$ ), located in the south-east of the Bay of Biscay (Fig. 1). The tidal prism of the bay was estimated to be 384 million cubic meters for a mean tide and the flushing time of the bay ranges between 12.4 to 17.4 days (Plus et al., 2009). Fresh water inputs represent a mean annual volume of about 813 million cubic meters, with the main river - the Eyre contributing to about $73 \%$ of total inflows. The two phanerogam species growing in the Bay - dwarfgrass (Zostera noltei) on tidal flats, and eelgrass (Z. marina) on the channel edges - suffered a severe decline between 1988 and 2008 (Plus et al., 2010). According to this study, more than one third of the Zostera beds were lost within twenty years with a worsening effect from the year 2005 onwards, and the situation does not seem to have changed since that time (I. Auby, pers. comm.). The causes remain unclear even if several explanations with possible synergy are currently being investigated: heat waves during summers 2003 and 2006, pesticide contamination, direct physical damage due to clam harvesting activities and seagrass decline contributing to mud resuspension and thus reducing, like in a vicious circle, the available light for seagrass growth.

It is likely that an event of such a magnitude has caused changes in the biogeochemical status of the Arcachon Bay. The first indications of changes due to seagrass regression are for example the increase in ammonium concentration in the water column (Plus et al., 2010) as well as the impact on the local flows leading to modifications in sediment erosion and deposition rates (Kombiadou et al., 2014). Furthermore, a net release of ammonium as well as a drop in the reactive $\mathrm{P}$ stock in the 
sediments was found (Delgard et al., 2013). All these changes may consequently have impacted macrophyte, phytoplankton, and seagrass contributions to the total production and biogeochemical cycles of the Bay.

In this study, we propose a mathematical model coupling hydrodynamics with ecological processes, to be used as a tool to investigate the different pathways of organic matter production in the Arcachon Bay (phytoplankton, macroalgae and phanerogams), their impacts on biogeochemical cycles (nitrogen, phosphorus and silicon cycles) and the fate of the produced organic matter, in the context of drastic seagrass reduction. We also hope that the information provided by this model, as well as its capability to simulate theoretical scenarios will be beneficial to policy makers who can use it as a tool for the management of coastal zones.

\section{Materials and methods}

\subsection{Description of the mathematical model}

The hydrodynamic model developed for the Arcachon Bay is MARS-3D: Model for Applications at Regional Scale. A detailed description of the MARS-3D model is available in Lazure and Dumas (2008), and this model has been previously applied to the Arcachon case for a barotropic hydrodynamic description of the Bay (Plus et al., 2009). In this study, the MARS-3D model is designed with grid limits between $44^{\circ} 21^{\prime} \mathrm{N}-44^{\circ} 54^{\prime} \mathrm{N}$ and $0^{\circ} 57^{\prime} \mathrm{W}-1^{\circ} 27^{\prime} \mathrm{W}$, and with a spatial horizontal resolution of $235 \mathrm{~m} \times 235 \mathrm{~m}$ (squared grid) and 10 layers on the vertical with sigma coordinates (the thickness of vertical meshes varies proportionally with depth). Time steps varied between 15 and 200 seconds in order to maintain the Courant-Friedrichs-Lewy stability criterion (

$\frac{\mathrm{u} . \Delta t}{\Delta x}$, with u the current speed, $\Delta x$ the horizontal resolution and $\Delta t$, the time step) below 0.6. Our model is forced at the boundaries for free surface elevation, water temperature and salinity by a model simulating the Bay of Biscay hydrodynamics which has been previously validated for tides and hydrology (Lazure et al., 2009). Atmospheric conditions throughout the area - air temperature, 
atmospheric pressure, nebulosity, relative humidity - are provided by the Arpege Météo-France model. The model bathymetry resulted from combined datasets: L'Yavanc (1995) for the Arcachon lagoon, the SMNG (Service Maritime de Navigation de la Gironde) for the sandy inlets area, and the SHOM (Service Hydrographique et Océanographique de la Marine) for the open ocean.

The biochemical model (see the conceptual diagram on Figure 2) is an extension of the NPZD model type (Nutrient-Phytoplankton-Zooplankton-Detritus), aiming to simulate the fluxes of limiting elements such as nitrogen $(\mathrm{N})$, phosphorus $(\mathrm{P})$ and silicon $(\mathrm{Si})$. It takes into account three primary producers: phanerogams, micro- and macroalgae. For the phanerogams, we chose to consider only Zostera noltei since this species largely dominates in the Arcachon Bay (Auby and Labourg, 1996, Plus et al., 2010). In order to approach the community composition and the phenology of the Arcachon Bay phytoplankton, the model simulates 2 different size classes : microphytoplankton and piconanophytoplankton. According to Glé et al. $(2007,2008)$ diatoms largely dominate the microphytoplankton in the Arcachon Bay, always contributing to more than $80 \%$ of the total abundance for that size class. We thus considered that microphytoplankton is a diatom-dominated group whose growth is $\mathrm{N}, \mathrm{P}$ and $\mathrm{Si}$ dependent whilst pico-nanophytoplankton is a smaller size-class group with a $\mathrm{N}$ and P-dependent growth. In other terms, our model does not take into account the small diatoms (size $<2 \mu \mathrm{m}$ ) that are part of the pico-nanophytoplankton. Lastly, a third group aims to simulate autotrophic flagellates with a $\mathrm{N}$ and P-dependent growth.

Contrary to the phytoplankton, the model takes into account the $\mathrm{N}$ and $\mathrm{P}$ quotas for macroalgae and for phanerogams. Thus, the formulation of growth as well as $\mathrm{N}$ and $\mathrm{P}$ uptakes differs whether it concerns the phytoplankton or the macrophytes. On the one hand, phytoplankton growth will depend directly and instantaneously on nutrient concentrations in the surrounding waters, whilst on the other hand, following Droop's model (1970), macroalgae and phanerogams growth will depend on internal $\mathrm{N}$ and $\mathrm{P}$ quotas (additional state variables), thus allowing the replenishment of nutrient reserves even during periods of slow growth. Moreover, in the case of the phanerogams (Zostera state variables), 
nutrient uptake by leaves as well as by roots is taken into account. Finally, growth is obviously controlled by water temperature and available light, whatever the type of primary producer.

Grazers are split into two groups, microzooplankton and mesozooplankton which graze on all size classes regarding the former and only on microphytoplankton and dinoflagellates regarding the latter. Although heterotrophic bacteria biomass is not explicitly described in the model, the biogeochemical cycles are closed by equations of mineralization of particulate organic matter (detritus). Grazing on bacteria is not taken into account except for autotrophic bacteria that are included in the piconanophytoplankton. Two kinds of detritus are highlighted in the model, labile detritus coming from phytoplankton, zooplankton and macroalgae senescence, and refractory detritus coming from dwarfgrass leaves, rhizomes and root decay. Both detritus types are mineralized and contribute to the nutrient renewal but the differences in decomposition rates could be substantial (Enriquez et al., 1993, Bourguès et al., 1996). We estimate that the decomposition rate of refractory detritus is about ten times slower than that of labile detritus. The available light for primary production (PAR) is calculated from incident solar radiations in the spectral range 400 to $700 \mathrm{~nm}$, limited by cloud cover (provided by meteorological forcing, METEO-FRANCE model ARPEGE), phytoplankton biomass (simulated) selfshading and suspended particulate matter SPM (supplied by IFREMER-ARCHYD dataset, unpublished data). N, P and Si riverine inputs were calculated on the basis of volumes river flow provided by the DIREN (Governmental Environment Agency) and the nutrient concentrations by the SIBA (Syndicat Intercommunal du Bassin d'Arcachon).

All the model equations have been previously detailed in several papers: Loyer et al. (2001) and Huret et al. (2013) for the biogeochemical cycling and the planktonic network, Plus et al. (2003) for the Z. noltei sub-model, Ménesguen et al. (2006) for the green macroalgae sub-model. To our knowledge, all the above mentioned sub-models have never been used together, and the originality of this work lies in the coupling of all these ecological sub-models with hydrodynamics. Annual simulations were made possible thanks to CAPARMOR calculator (up to 27 teraflops of computing 
power). All equations and parameters can be consulted on the MARS-3D technical documentation (IFREMER-Dyneco, 2012).

\subsection{Validation}

The model performance was assessed by comparing observations and model simulations according to the methods proposed by Piñeiro et al. (2008). Seawater temperature (TEMP) and salinity (SAL) data were taken from the IFREMER-ARCHYD database, at four different stations in the Bay. Sea surface height (SSH) observations at the Eyrac tide gauge were provided by the REFMAR website (www.refmar.shom.fr/ ARCACHON_EYRAC) and remain the property of SHOM (Naval Hydrographic and Oceanographic Service) and the Gironde DDTM (Sea and Territory Departmental Directorate). The model validation results concerning physical variables (SSH, TEMP and SAL) were recently published by Binias et al. (2014) and are summarized in Table 1.

Figure 3 shows simulations versus field experimental data for several biogeochemical variables (source IFREMER-ARCHYD database) over a yearly period (2009 was chosen for observations/simulations comparison). It appears that the model reproduces satisfactorily the order of magnitude as well as the seasonal patterns of physical and biogeochemical variables. Spatial gradients of physical and ecological variables are also well represented by the model. Nevertheless the validation stresses that extremes (high or low values for biological variables) have not been properly found by the model. As an example, the simulated amplitude of the annual variations in total chlorophyll $a$ at the outer most station Buoy 7 is too low when compared to ARCHYD data in 2009, leading to an underestimation of the maximum levels (late winter, spring) as well as an overestimation of the minimum summer levels of chlorophyll $a$ by the model. Likewise, the model gives very low values of nutrients (especially dissolved silicon and dissolved phosphorus) which might be due to an underestimation of internal remineralisation processes during the summer. Notwithstanding these limitations, we think that the model is able to give relevant information on the inter-annual variation of overall primary production and biogeochemical cycles in the Arcachon Bay during the study period. 


\subsection{Simulations}

Two annual simulations (years 2005, 2007) were run in order to investigate the impact of Zostera beds regression on the lagoon primary production and on the biogeochemical cycles. We took advantage of two seagrass mapping surveys performed in 2005 and 2007 (Plus et al., 2010) to initialize the seagrass beds extension in the model. Zostera biomass in winter (beginning of the simulations) was arbitrarily calibrated in order to fit Ganthy et al. (2013) 2009 data at station Germanan (see Figure 3), and the spatial distribution of Zostera biomass was assessed thanks to the cover classes recorded during the mapping surveys.

Two more simulations were performed for the year 2009 in order to test the hypothesis of the total disappearance of Zostera beds. Due to the absence of an extension map in 2009, seagrass extension was considered to be equal to that of the year 2007 and the run was compared with the 'no Zostera bed' scenario, where all Zostera variables were set to zero at the beginning of the simulation.

We chose to focus on the net production at the scale of the whole lagoon for the three groups of primary producers and on the respective total nitrogen and phosphorus uptakes. The model also allowed suggested/estimated annual budgets, as an assessment of the quantities of carbon inflow (riverine inputs), fixed within (primary production) and exported out (due to advection) of the system. Conversions from nitrogen to carbon were calculated thanks to the following molar $\mathrm{C} / \mathrm{N}$ ratios: 6.625 for phytoplankton and labile organic matter (Redfield, 1973), 16.8 and 15.8 respectively for refractory organic matter and macroalgae (Plus et al., 2005) and 14 for riverine organic matter (Dubois et al., 2012). For all calculations we assumed the Ferret Cape meridian $\left(1^{\circ} 15^{\prime} \mathrm{W}\right)$ as the separation line between the ocean and the Arcachon Bay.

\section{Results}

Table 2 shows the calculated net annual primary production values for the different years and scenarios. The total annual production for the Arcachon Bay (except the microphytobenthos not included in the present study) ranged between 22,900 (year 2007) and 35,300 (year 2005) tons of 
carbon per year. In all the periods considered, the main primary producers in the lagoon were Zostera beds, reaching a maximum of $81 \%$ of total production in 2005 . According to the model, the severe seagrass decay observed between 2005 and 2007 (ca -30\%) went along with a 55\% reduction in annual seagrass production. Within the same period, phytoplankton and macroalgae enhanced their production by $46 \%$ and $83 \%$ respectively. The annual phytoplankton production always stayed about eight fold greater than the macroalgae production. The simulations for the year 2009 show that phytoplankton probably took more advantage of the total disappearance of seagrass beds than the macroalgae with a production increase of $+28 \%$ (respectively 17\%). According to that scenario, the overall annual lagoon production (excluding the microphytobenthos) probably suffered a $-55 \%$ drop. The model also stresses that large diatoms dominated the phytoplankton community in terms of biomass (respective annual mean diatom, pico-nanophytoplankton and flagellate biomasses were 38.7, 19.6 and 1.5 tons of $\mathrm{C}$ in 2005 and 40.3, 28.4 and 1.6 tons of $C$ in 2007) despite a higher production of smaller groups (pico-nanophytoplankton, see Table 2). Within phytoplankton, the piconanophytoplankton took more advantage of the seagrass reduction than the diatoms. In fact, the piconanophytoplankton enhanced its production by a factor of 1.6 between 2005 and 2007 whilst the diatoms and the flagellates multiplied their production by 1.2 and 1.3 respectively.

We also compared the different primary producers in terms of N, P and Si global uptakes (Table 3). Due to the differences between groups regarding the $\mathrm{C} / \mathrm{N} / \mathrm{P}$ ratios (higher ratios for the seagrasses than for the phytoplankton or the macroalgae), to the differences in biomasses, and to the mechanism of $\mathrm{N}$ and P stocks in the plants, phytoplankton represented, as expected, the major uptake compartment in the Bay. It is moreover important to notice that the inter-annual variations of riverine inputs were very high. The calculated riverine N input during 2009 was for instance more than twice as high as in 2005. These results (Table 3) show, that continental inputs of nitrogen, phosphorus and silicon ranged respectively $26-52 \%, 1.1-2.2 \%$ and $73-100 \%$ of total annual uptakes. Adding the estimations for particulate organic matter, the continental riverine annual inputs probably made up 34-73\% and 6-13\% the $\mathrm{N}$ and $\mathrm{P}$ total uptakes, respectively. 
As already mentioned, the model couples hydrodynamics with ecological processes, and it is thus possible to calculate the advective fluxes of particulate organic carbon (POC) in and out of the lagoon. Figure 4 presents the years 2005 and 2007 budgets for carbon fluxes and for mean stocks of carbon calculated by the model. In 2005 (resp. 2007) about 8\% (resp. 10\%) of the global lagoon production (excluding the microphytobenthos) was exported to the ocean according to the model. The exported matter was mainly composed ( $86 \%$ in 2005 and $67 \%$ in 2007) of refractory detritus coming from the continuous renewal of seagrass leaves. The 2005 situation is characterized by a high production, low riverine input and high stocks of carbon rich organic matter, whereas in 2007 the production was 35\% lower despite higher riverine input. Moreover, the calculated proportion of labile OM in the lagoon was higher in 2007 than in 2005.

\section{Discussion}

The model presented in this study allowed us (i) to propose an assessment of the phytoplankton, macroalgae and phanerogam contributions to the total primary production of the Arcachon lagoon, (ii) to evaluate their respective impacts on the main biogeochemical cycles and (iii) to calculate annual budgets over several years, within the observed context of a seagrass bed reduction. The main idea put forward by this study is that the ongoing seagrass decay coincides with an increase in phytoplankton and macroalgae production and a decrease in the overall primary production. This entails an inprogress modification of the biogeochemical equilibrium such as for instance a shift towards the production of more labile organic matter between 2005 and 2009.

Glé et al. (2008) estimated an annual phytoplankton production of $103 \mathrm{~g} \mathrm{C} \mathrm{m}^{-2} \mathrm{y}^{-1}$ in the Arcachon Bay for the year 2003, which is lower but close to our estimations for the years 2005 and 2007. Our results are furthermore in the same order of magnitude as other experimentally derived production data for temperate lagoons (Table 4), but place the algal production of the Arcachon Bay in the lower range of temperate lagoons. 
Eutrophication does not seem to be of major concern since nutrient inputs in the Arcachon Bay are rather moderate (De Wit et al., 2001) and high tidal flushing prevents the confinement of waters (Plus et al., 2009). According to the model, the inorganic nitrogen river inputs ranged between 479 and 1,075 tons (years 2005, 2007 and 2009) which is lower but close to estimates made by De Wit et al. (2005) for the years 1996-1999 $(1,114 \mathrm{t} \mathrm{N})$, and the differences may be attributed to the inter-annual variations of precipitation and river flows (mean Eyre river flow was $15.5 \mathrm{~m}^{3} \mathrm{~s}^{-1}$ between 1996 and 1999, and 8.7, 12.9 and $14.7 \mathrm{~m}^{3} \mathrm{~s}^{-1}$ respectively in 2005, 2007 and 2009, according to the DIRENGovernmental Environment Agency). Nitrogen river inputs to the lagoon are moreover much higher than inputs due to direct rainfall $(89 \mathrm{t} \mathrm{N}$, according to Auby et al., $1994 ; 81 \mathrm{t} \mathrm{N}$, according to Rimmelin et al., 1998) or by aquifers (6.1 t N according to Rimmelin et al., 1998). Comparisons between the annual quantities of N, P and Si brought by the rivers and the annual uptakes due to the primary producers exhibit that the major part of $\mathrm{N}$ and $\mathrm{Si}$ demand is brought to the Bay by the rivers (up to $73 \%$ and $100 \%$ of $\mathrm{N}$ and Si respectively), while for $\mathrm{P}$ demand, the riverine contribution is much less and accounts for only $13 \%$ of total demand. These results underline the importance of the internal mineralization of organic matter (microbial loop), in sustaining primary production in the Arcachon Bay.

The model shows that the reduction of the extension in seagrass beds and consequently the resulting loss of production is neither compensated by phytoplankton nor by macroalgae. Between 2005 and 2009, the micro- and macroalgal production increased but not sufficiently to compensate the gap left by seagrass reduction, even if the continental nutrient inputs were higher in 2009 than in 2005 (Table 2 and 3). The 2009 simulations with and without Zostera beds (but with the same environmental conditions) also stressed that green macroalgae benefit surprisingly little from the seagrass decline. This was different when the Arcachon Bay suffered from an increase in nitrogen riverine inputs during the early 1990s facilitating macroalgal (Monostroma obscurum) blooms (Castel et al., 1996). Since that time, the levels of nitrogen inputs have been reduced and nutrient concentrations seem to be too low to produce such proliferations. In fact, the model simulates to a great extent the same levels of N, P and Si limitations in the presence or absence of seagrasses (data 
not shown), It is thus likely that the Arcachon lagoon is currently the location of only moderate nutrient competition between seagrasses and other primary producers. Furthermore, seagrasses can take up nutrients from the sediment, thus maintaining high production rates even during the summer when nutrient scarcity prevails in the water column. On the other hand, the model also highlights that the decline in seagrass beds tends to modify the phytoplankton community composition. The main beneficiary seems to be pico-nanophytoplankton during the summer period, when conditions are favourable to small species (low nutrient concentrations, high light and temperature levels), whilst larger diatoms show only a small increase in productivity.

The simulated phytoplankton $\mathrm{N}$ uptake (resp. P uptake) is 1.5 to 3.5 (resp. 1.3 to 2.8 ) times higher than the seagrass uptake at the scale of the whole lagoon. Nonetheless, the quality of the organic matter produced is not the same and higher mineralisation rates suggest that it is more likely to be recycled inside the Bay than exported. The annual budgets show that the mean annual proportion of refractory POC in the Bay dropped from 69\% to 55\% between 2005 and 2007, and that less organic carbon was exported out of the system in 2007 (-180 tons of carbon), despite a 2.3 times higher inflow of continental POC. Taking into account the differences in C:N:P ratios for phytoplankton, macroalgae and seagrasses, it is likely that these changes will impact the biogeochemical cycles and modify the phytoplankton community phenology. Further developments of the model are nonetheless needed to study this impact.

All the assessments proposed in the present study have to be considered with caution, keeping in mind the following weaknesses of the model. First of all, this study is entirely theoretical, and even if the model outputs have been checked by comparing with experimental datasets (Table 1, Figure 3) and the different parameters constrained in the commonly accepted ranges, the real validation only concerns physical variables and very few biological variables. The results presented here should be considered within a certain range and we think that the interest probably lies more in the simulations collation rather than in the absolute values. To use such coupled hydrodynamic-ecological deterministic models, a lot of progress still remains to be achieved, not only concerning the formulation of biological processes but also the numerical programming and the computing capacities, 
before it is possible to simulate the huge complexity of coastal systems. As an example, recent studies have shown the very complex interactions that exist between phytoplankton and Zostera beds. These interactions go far beyond the "simple" competition for light and nutrients that is simulated in our model and probably encompass direct (allelopathic substances) and indirect (modifications of benthic suspension feeder communities etc.) factors affecting phytoplankton densities (De Wit et al., 2012). Secondly, some studies have underlined the importance of microphytobenthos production in other temperate lagoons (Nienhuis \& De Bree, 1984; Strusky \& Bacher, 2006; Migné et al., 2004), with productions of the same order of magnitude as phytoplankton and even higher. The reason why this primary producer was not included in our model is due to the absence of experimental data regarding that compartment for the Arcachon Bay, as far as we know. In the Marennes-Oléron Basin (about 200 $\mathrm{km}$ north of the Arcachon Bay, mean depth $3.6 \mathrm{~m}$ ), microphytobenthos is mainly composed of pennate diatoms that are constantly oscillating between pelagic and benthic lives through erosion/deposition processes and contribute in fuelling both benthic and pelagic trophic chains (Guarini et al., 2000; Blanchard et al., 2001). Moreover, the reduction of Zostera beds in Arcachon has created more space for large intertidal bare mudflats which may have been colonized by benthic microalgae. Our assessment of microalgae production thus very probably underestimates this compartment and needs to be included in a future version of our model.

\section{Conclusion}

Like other lagoonal systems, the Arcachon Bay is highly productive and the location of intense internal remineralisation. The recent decline in seagrass beds does not seem to have led to an outbreak of more opportunistic and short-life species (macroalgae, phytoplankton) although phytoplankton seems to have enhanced its production. This is probably due to the somewhat reduced continental nutrient inflows. Our model shows that the overall productivity has begun to shift from a system mainly based on refractory organic matter towards a more instable system based on a more labile organic matter production. 


\section{ACKNOWLEDGEMENTS}

This study was conducted within the framework of the scientific ANR-IZOFLUX and the OSQUAR (Regional Council of Aquitaine) programs. We would like to thank the two anonymous reviewers for their constructive corrections and comments that helped to improve an earlier version of this manuscript.

\section{REFERENCES}

Auby, I., Manaud, F., Maurer, D., Trut, G., 1994. Etude de la prolifération des algues vertes dans le Bassin d'Arcachon. IFREMER Scientific \& technical Report, Arcachon, 162 pp.

Auby, I., Labourg, P.-J., 1996. Seasonal dynamics of Zostera noltii Hornem. in the bay of Arcachon (France). Journal of Sea Research 35, 269-277.

Azevedo, I. C., Bordalo, A. A., \& Duarte, P., 2014. Influence of freshwater inflow variability on the Douro estuary primary productivity: A modelling study. Ecological Modelling, 272, 1-15.

Binias, C., Tu Do, V., Jude-Lemeilleur, F., Plus, M., Froidefond, J.-M., de Montaudouin, X., 2014. Environmental factors contributing to the development of brown muscle disease and perkinsosis in Manila clams (Ruditapes philippinarum) and trematodiasis in cockles (Cerastoderma edule) of Arcachon Bay. Marine Ecology 35, 67-77.

Blanchard, G. F., Guarini, J.-M., Orvain, F., Sauriau, P.-G., 2001. Dynamic behaviour of benthic microalgal biomass in intertidal mudflats. Journal of Experimental Marine Biology and Ecology $264,85-100$.

Bourguès, S., Auby, I., De Wit, R., Labourg, P.-J., 1996. Differential anaerobic decomposition of seagrass (Zostera noltii) and macroalgal (Monostroma obscurum) biomass from Arcachon Bay (France). Coastal Lagoon Eutrophication and ANaerobic Processes (C.L.E.AN.), Developments in Hydrobiology 117, 121-131. 
Cloern, JE, 2001. Our evolving conceptual model of the coastal eutrophication problem. Mar Ecol Prog Ser 210: 223-253.

Deborde, J., Abril, G., Mouret, A., Jzquel, D., Thouzeau, G., Clavier, J., Bachelet, G., Anschutz, P., 2008. Effects of seasonal dynamics in a Zostera noltii meadow on phosphorus and iron cycles in a tidal mudflat (Arcachon Bay, France). Marine Ecology Progress Series 355, 59-71.

Delgard, M.-L., Deflandre, B., Deborde, J., Richard, M., Charbonnier, C., Anschutz, P., 2013. Changes in nutrient biogeochemistry in response to the regression of Zostera noltii meadows in the Arcachon Bay (France). Aquat. Geochem. 19, 241-259.

De Wit, R., Leibreich, J., Vernier, F., Delmas, F., Beuffe, H., Maison, P., ... \& Capdeville, P. (2005). Relationship between land-use in the agro-forestry system of les Landes, nitrogen loading to and risk of macro-algal blooming in the Bassin d'Arcachon coastal lagoon (SW France). Estuarine, Coastal and Shelf Science, 62(3), 453-465.

De Wit, R., Troussellier, M., Courties, C., Buffan-Dubau, E., Lemaire, E., 2012. Short-term interactions between phytoplankton and intertidal seagrass vegetation in a coastal lagoon (Bassin d'Arcachon, SW France). Hydrobiologia 699, 55-68.

De Wit, R., Stal, L. J., Lomstein, B. A., Herbert, R. A., van Gemerden, H., Viaroli, P., Cecherelli, V.U., Rodríguez-Valera, F., Bartoli, M., Giordani, G., Azzoni, R., Schaub, B., Welsh, D. T., Donnelly, A., Cifuentes, A., Antón, J., Finster, K., Nielsen, L. B., Underlien Pedersen, A.-G., Neubauer, A. T., Colangelo, M. A., Heijs, S. K., 2001. ROBUST: The ROle of BUffering capacities in STabilising coastal lagoon ecosystems. Continental Shelf Research 21, 2021-2041.

Duarte, P., Azevedo, B., Guerreiro, M., Ribeiro, C., Bandeira, R., Pereira, A., ... and Reia, J. (2008). Biogeochemical modelling of Ria Formosa (South Portugal). Hydrobiologia, 611, 115-132.

Dubois, S., Savoye, N., Grémare, A., Plus, M., Charlier, K., Beltoise, A., Blanchet, H. (2012). Origin and composition of sediment organic matter in a coastal semi-enclosed ecosystem: An elemental and isotopic study at the ecosystem space scale. Journal of Marine Systems, 94, 64-73.

Duffy, J. E., Richardson, J. P., France, K. E., 2005. Ecosystem consequences of diversity depend on food chain length in estuarine vegetation. Ecology Letters 8, 301-309. 
Enríquez, S., Duarte, C., Sand-Jensen, K., 1993. Patterns in decomposition rates among photosynthetic organisms: the importance of detritus C:N:P content. Oecologia 94, 457-471.

Ganthy, F., Soissons, L., Sauriau, P.-G., Verney, R., Sottolichio, A., 2014. Effects of short flexible seagrass Zostera noltei on flow, erosion and deposition processes determined using flume experiments. Sedimentology 62, 997-1023.

Ganthy,,F., Sottolichio, A., Verney, R., 2013. Seasonal modification of tidal flat sediment dynamics by seagrass meadows of Zostera noltii (Bassin d'Arcachon, France). Journal of Marine Systems 109-110, S233-S240.

Gattuso, J.-P., Frankignoulle M., Wollast R., 1998. Carbon and carbonate metabolism in coastal aquatic ecosystems. Annual Review of Ecology and Systematics 29, 405-434.

Glé, C., Del Amo, Y., Bec, B., Sautour, B., Froidefond, J.-M., Gohin, F., Maurer, D., Plus, M., Laborde, P., Chardy, P., 2007. Typology of environmental conditions at the onset of winter phytoplankton blooms in a shallow macrotidal coastal ecosystem, Arcachon Bay (France). Journal of Plankton Research 29, 999-1014.

Glé, C., Del Amo, Y., Sautour, B., Laborde, P., Chardy, P., 2008. Variability of nutrients and phytoplankton primary production in a shallow macrotidal coastal ecosystem (Arcachon Bay, France). Estuarine, Coastal and Shelf Science 76, 642-656.

Gray J. S., 1997. Marine biodiversity: patterns, threats and conservation needs. Biodiversity and conservation $6,153-175$.

Guarini, J. M., Blanchard, G. F., Gros, P., Gouleau, D., Bacher, C., 2000. Dynamic model of the shortterm variability of microphytobenthic biomass on temperate intertidal mudflats. Marine Ecology Progress Series 195, 291-303.

Harding, L. W., Mallonee, M. E., Perry, E. S., 2002. Toward a Predictive Understanding of Primary Productivity in a Temperate, Partially Stratified Estuary. Estuarine, Coastal and Shelf Science 55, 437-463. 
Heck, K.L.J., Carruthers, T. J. B., Duarte, C. M., Hughes, A. R., Kendrick, G., Orth R. J., Williams S. W., 2008. Trophic transfers from seagrass meadows subsidize diverse marine and terrestrial consumers. Ecosystems 11, 1198-1210.

Huret, M., Sourisseau, M., Petitgas, P., Struski, C., Léger, F., Lazure, P., 2013. A multi-decadal hindcast of a physical-biogeochemical model and derived oceanographic indices in the Bay of Biscay. Journal of Marine Systems 109-110, S77-S94.

IFREMER-Dyneco, 2012. Technical documentation of the model MARS-3D. http://www.ifremer.fr/docmars/html/documentation.html.

Jensen, S.I., Kühl, M., Glud, R.N., Jorgensen, L.B., Priemé, A., 2005. Oxic microzones and radial oxygen loss from roots of Zostera marina. Marine Ecology Progress Series 293, 49-58.

Kimmerer, W. J., Parker, A. E., Lidström, U. E., Carpenter, E. J., 2012. Short-term and interannual variability in primary production in the low-salinity zone of the San Francisco Estuary. Estuaries and Coasts 35, 913-929.

Kombiadou, K., Ganthy, F., Verney, R., Plus, M., Sottolichio, A., 2014. Modelling the effects of Zostera noltei meadows on sediment dynamics: application to the Arcachon lagoon. Ocean Dynamics 64, 1-18.

Lancelot, C., Staneva, J., Van, E., Beckers, J.-M., Stanev, E., 2002. Modelling the Danube-influenced north-western continental shelf of the Black Sea. II. Ecosystem response to changes in nutrient delivery by the Danube river after its damming in 1972. Estuarine, Coastal and Shelf Science 54, 473-499.

Lazure, P., Garnier, V., Dumas, F., Herry, C., Chifflet, M., 2009. Development of a hydrodynamic model of the Bay of Biscay. Validation of hydrology. Continental Shelf Research 29, 985-997.

Lazure, P., Dumas, F., 2008. An external-internal mode coupling for a 3D hydrodynamical model for applications at regional scale (MARS). Advances in Water Resources 31, 233-250.

Loyer, S., Lazure, P., Gentien, P., Ménesguen, A., 2001. Modelling of Gymnodinium mikimotoi blooms along the French Atlantic coast: geographical and vertical distributions. Hydroécol. Appl. $13,57-76$. 
L'Yavanc, J., 1995. Evolution bathymétrique et morphologique du Bassin d'Arcachon. Ifremer Report DEL 12-95 (in french), 82pp. Unpublished.

Ménesguen, A., Cugier, P., Leblond, I., 2006. A new numerical technique for tracking chemical species in a multisource, coastal ecosystem applied to nitrogen causing Ulva blooms in the Bay of Brest (France). Limnol. Oceanogr. 51, 591-601.

Migné, A., Spilmont, N., Davoult, D., 2004. In situ measurements of benthic primary production during emersion: seasonal variations and annual production in the Bay of Somme (eastern English Channel, France). Continental Shelf Research 24, 1437-1449.

Nienhuis, P. H., De Bree, B. H. H., 1980. Production and growth dynamics of eelgrass (Zostera marina) in brackish Lake Grevelingen (The Netherlands). Netherlands Journal of Sea Research 14, $102-118$

Nienhuis, P. H., De Bree, B. H. H., 1984. Carbon fixation and chlorophyll in bottom sediments of brackish Lake Grevelingen,The Netherlands. Netherlands Journal of Sea Research 18, 337-359.

Piñeiro, G., Perelman, S., Guerschman, J.P., Paruelo, J., 2008. How to evaluate models: observed versus predicted or predicted versus observed ? Ecological Modelling 216, 316-322.

Plus, M., Auby, I., Verlaque, M., Levavasseur, G. (2005). Seasonal variations in photosynthetic irradiance response curves of macrophytes from a Mediterranean coastal lagoon. Aquatic Botany 81: $157-173$.

Plus, M., Dalloyau, S., Trut, G., Isabelle, A., De Montaudouin, X., Emery, E., Claire, N., Christophe, V., 2010. Long-term evolution (1988-2008) of Zostera spp. meadows in Arcachon Bay (Bay of Biscay). Estuarine, Coastal and Shelf Science 87, 357-366.

Plus, M., Dumas, F., Stanisière, J.-Y., Maurer, D., 2009. Hydrodynamic characterization of the Arcachon Bay, using model-derived descriptors. Continental Shelf Research 29, 1008-1013.

Rimmelin, P., Dumon, J. C., Maneux, E., Gonçalves, A., 1998. Study of annual and seasonal dissolved inorganic nitrogen inputs into the Arcachon Lagoon, Atlantic Coast (France). Estuarine, Coastal and Shelf Science 47, 649-659. 
Sfriso, A., Marcomini, A., Pavoni, B., Orio, A. A., 1993. Species composition, biomass, and net primary production in shallow coastal waters: The Venice lagoon. Bioresource Technology 44, 235-249.

Struski, C., Bacher, C., 2006. Preliminary estimate of primary production by phytoplankton in Marennes-Oléron Bay, France. Estuarine, Coastal and Shelf Science 66, 323-334.

Vegter, F., \& De Visscher, P. R. M. (1984). Phytoplankton primary production in brackish Lake Grevelingen (SW Netherlands) during 1976-1981. Netherlands journal of sea research, 18(3), 246259.

Waycott, M., Duarte, C.M., Carruthers, T.J.B., Orth, R.J., Dennison, W.C., Olyarnik, S., Calladine, A., Fourqurean, J.W., Heck, K.L., Hughes, A.R., Kendrick, G.A., Kenworthy, W.J., Short, F.T., Williams, S.L., 2009. Accelerating loss of seagrasses across the globe threatens coastal ecosystems. Proceedings of the National Academy of Sciences 106, 12377-12381.

Welsh, D.T., Bartoli, M., Nizzoli, D., Castaldelli, G., Riou, S., Viaroli, P., 2000. Denitrification, nitrogen fixation, community primary productivity and inorganic-N and oxygen fluxes in an intertidal Zostera noltii meadow. Marine Ecology Progress Series 208, 65-77.

Wium-Andersen, S., Borum, J., 1984. Biomass variation and autotrophic production of an epiphytemacrophyte community in a coastal Danish area : I. Eelgrass (Zostera marina L.) biomass and net production. Ophelia 23, 33-46.

Zaldívar, J.M., Bacelar, F.S., Dueri, S., Marinov, D., Viaroli, P., Hernández-García, E., 2009. Modeling approach to regime shifts of primary production in shallow coastal ecosystems. Ecological Modelling 220, 3100-3110. 


\section{TABLES}

Table 1. Model evaluation results for tides (sea surface height, SSH), temperature (TEMP) and salinity (SAL). Regression parameters (slope $\mathrm{a}$ and bias $\mathrm{b}$, for the Yobs $=\mathrm{aYmod}+\mathrm{b}$ equation), coefficient of determination $\left(\mathrm{r}^{2}\right)$, Ubias, Uslope and Uerror (Theil's partial inequality coefficients), are the proportions of observed variance not explained by the model and due to mean differences between observed and predicted values, slope error and unexplained variance, respectively), root mean-squared deviation $\left(R M S D=\sqrt{\frac{\sum_{1}^{n}(Y i m o d-Y i o b s)^{2}}{n-1}}\right)$ for the observed $\left(Y_{i} o b s\right)$ versus predicted $\left(Y_{i} m o d\right)$ variables. (Adapted from Binias et al., 2014).

\begin{tabular}{llll}
\hline & SSH & TEMP & SAL \\
\hline $\mathrm{a}$ (significance of test $\mathrm{a}=1)$ & $1.008(\mathrm{p}=0.20)$ & $0.958(\mathrm{p}=0.09)$ & $0.910(\mathrm{p}=0.18)$ \\
$\mathrm{b}$ (significance of test $\mathrm{b}=0)$ & $0.016(\mathrm{p}=0.33)$ & $0.376(\mathrm{p}=0.35)$ & $3.086(\mathrm{p}=0.16)$ \\
Degree of freedom & 915 & 34 & 34 \\
$\mathrm{r}^{2}$ & 0.97 & 0.98 & 0.85 \\
Ubias $(\%)$ & 0.034 & 0.125 & 0.039 \\
Uslope $(\%)$ & 0.002 & 0.071 & 0.049 \\
Uerror $(\%)$ & 0.964 & 0.804 & 0.912 \\
RMSD & 0.19 & 0.78 & 0.79 \\
\hline
\end{tabular}


Table 2. Annual net production $\left(10^{3} \mathrm{t} \mathrm{C}\right.$ year $\left.{ }^{-1}\right)$ simulated by the model for different years. Areas of Zostera noltei beds are recorded in brackets. For the simulation of the year 2009, two scenarios were run: with Zostera (+ zost), assuming the same total seagrass area as in 2007, and without Zostera (zost).

\begin{tabular}{lcccc}
\hline & 2005 & 2007 & \multicolumn{2}{c}{2009} \\
& & & + zost & - zost \\
\hline Total phytoplankton & 6.1 & 8.9 & 8.0 & 10.2 \\
Diatoms & 2.3 & 2.8 & 2.8 & 3.4 \\
Pico-nanophytoplankton & 3.7 & 6.0 & 5.2 & 6.7 \\
Flagellates & 0.07 & 0.09 & 0.08 & 0.09 \\
\hline Zostera noltei beds & 28.6 & 12.9 & 15.6 & - \\
& $\left(68 \mathrm{~km}^{2}\right)$ & $\left(42 \mathrm{~km}^{2}\right)$ & $\left(42 \mathrm{~km}^{2}\right)$ & $\left(0 \mathrm{~km}^{2}\right)$ \\
\hline Macroalgae & 0.6 & 1.1 & 1.2 & 1.4 \\
\hline
\end{tabular}


Table 3. Simulated annual nitrogen $(\mathrm{N})$, phosphorus $(\mathrm{P})$ or silicon $(\mathrm{Si})$ uptakes by the different primary producers $\left(\mathrm{t} \mathrm{N}, \mathrm{P}\right.$ or Si year $\left.{ }^{-1}\right)$ and continental annual inputs (particulate organic matter and inorganic dissolved nutrients, expressed in t N, P or Si year ${ }^{-1}$ ). Areas of Zostera noltei beds are recorded in brackets. For the simulation of the year 2009, two scenarios were run: with Zostera (+ zost), assuming the same seagrass area as in 2007, and without Zostera (- zost).

\begin{tabular}{|c|c|c|c|c|c|c|c|c|c|c|c|c|}
\hline & \multicolumn{3}{|c|}{2005} & \multicolumn{3}{|c|}{2007} & \multicolumn{3}{|c|}{2009 (+ zost) } & \multicolumn{3}{|c|}{2009 (- zost) } \\
\hline & $\mathrm{N}$ & $\mathrm{P}$ & $\mathrm{Si}$ & $\mathrm{N}$ & $\mathrm{P}$ & $\mathrm{Si}$ & $\mathrm{N}$ & $\mathrm{P}$ & $\mathrm{Si}$ & $\mathrm{N}$ & $\mathrm{P}$ & $\mathrm{Si}$ \\
\hline \multicolumn{13}{|l|}{ UPTAKES } \\
\hline Diatoms & 410 & 57 & 769 & 486 & 67 & 911 & 493 & 68 & 924 & 592 & 82 & 1,110 \\
\hline Pico-nanophytoplankton & 645 & 89 & - & 1,061 & 147 & & 909 & 126 & - & 1,180 & 163 & - \\
\hline Flagellates & 12 & 2 & - & 15 & 2 & & 14 & 2 & - & 16 & 2 & - \\
\hline Total phytoplankton & 1,067 & 148 & 769 & 1,562 & 216 & 911 & 1,416 & 196 & 924 & 1,788 & 247 & 1,110 \\
\hline \multirow{2}{*}{ Zostera noltei beds } & \multicolumn{3}{|c|}{$\left(68 \mathrm{~km}^{2}\right)$} & \multicolumn{3}{|c|}{$\left(42 \mathrm{~km}^{2}\right)$} & \multicolumn{3}{|c|}{$\left(42 \mathrm{~km}^{2}\right)$} & \multicolumn{3}{|c|}{$\left(0 \mathrm{~km}^{2}\right)$} \\
\hline & 717 & 114 & - & 439 & 78 & - & 484 & 82 & - & - & - & - \\
\hline Macroalgae & 76 & 2 & - & 138 & 5 & - & 179 & 5 & - & 197 & 7 & - \\
\hline \multicolumn{13}{|l|}{ CONTINENTAL INPUTS } \\
\hline Particulate organic matter & 153 & 13.7 & - & 346 & 21.9 & - & 446 & 31.5 & - & 446 & 31.5 & - \\
\hline Inorganic nutrients & 479 & 2.8 & 561 & 707 & 4.4 & 746 & 1,075 & 6.2 & 1,495 & 1,075 & 6.2 & 1,495 \\
\hline
\end{tabular}


Table 4. Levels of annual production reported for several temperate lagoons.

$\begin{array}{ll}\text { Region } & \text { Annual production References } \\ & \left(\mathrm{gC} \mathrm{m}^{-2} \mathrm{y}^{-1}\right)\end{array}$

\begin{tabular}{|c|c|c|c|}
\hline \multicolumn{4}{|l|}{ Phytoplankton } \\
\hline & Arcachon Bay & $110-161$ & Present study (model) \\
\hline & Lake Grevelingen & $60-225$ & Vegter \& De Visher (1984) \\
\hline & Marennes-Oléron & 185 & Strusky \&Bacher (2006) \\
\hline & Chesapeake Bay & $282-538$ & Harding et al. (2002) \\
\hline & San Fransisco Bay & $25-31$ & Kimmerer et al. (2012) \\
\hline \multicolumn{4}{|l|}{ Macroalgae } \\
\hline & Arcachon Bay & $11-22$ & Present study (model) \\
\hline & Venice Lagoon & $132-358$ & Sfriso et al. (1993) \\
\hline \multicolumn{4}{|l|}{ Zostera beds } \\
\hline & Arcachon Bay & $311-423$ & Present study (model) \\
\hline & Lake Grevelingen & $200-300$ & Nienhuis \& De Bree (1980) \\
\hline & $\emptyset$ resund & & Wium-Andersen \& Borum \\
\hline & & & (1984) \\
\hline
\end{tabular}




\section{FIGURE CAPTIONS}

Figure 1. The Arcachon Bay, general view and location of observation stations.

Figure 2. Simplified conceptual model for the biogeochemical model. Boxes represent state variables and arrows stand for the N, P, Si fluxes between state variables.

Figure 3. Observations (symbols) vs. simulation (lines) comparison for biological variables (concentrations of nitrate $\left[\mathrm{NO}_{3}\right]$, phosphate $\left[\mathrm{PO}_{4}\right]$, ammonium $\left[\mathrm{NH}_{4}\right]$, silicate $\left[\mathrm{Si}(\mathrm{OH})_{4}\right]$, chlorophyll a [Chl. a], and Zostera leaf biomass ZBL) at three different locations: Buoy 7 (in red), Comprian (in blue) and Germanan (in green). Chlorophyll $a$ is calculated on the basis of the sum of diatoms, piconanophytoplankton and dinoflagellates nitrogen biomass multiplied by a constant chlorophyll $a$ / $\mathrm{N}$ ratio of $1.59 \mathrm{~g} \mathrm{~mol}^{-1}$. Locations of the three experimental stations are reported on Figure 1.

Figure 4. Annual budgets of Arcachon Bay's carbon fluxes (2005, 2007, 2009 and 2009 with no Zostera meadows). The blue box stands for the lagoon, and red arrows represent the fluxes in and out of the system. Phytopk stands for the sum of all three phytoplankton variables, POC means particulate organic carbon. Fluxes are in $\mathrm{t} C$ year $^{-1}$ and stocks are in tons of $\mathrm{C}$. 


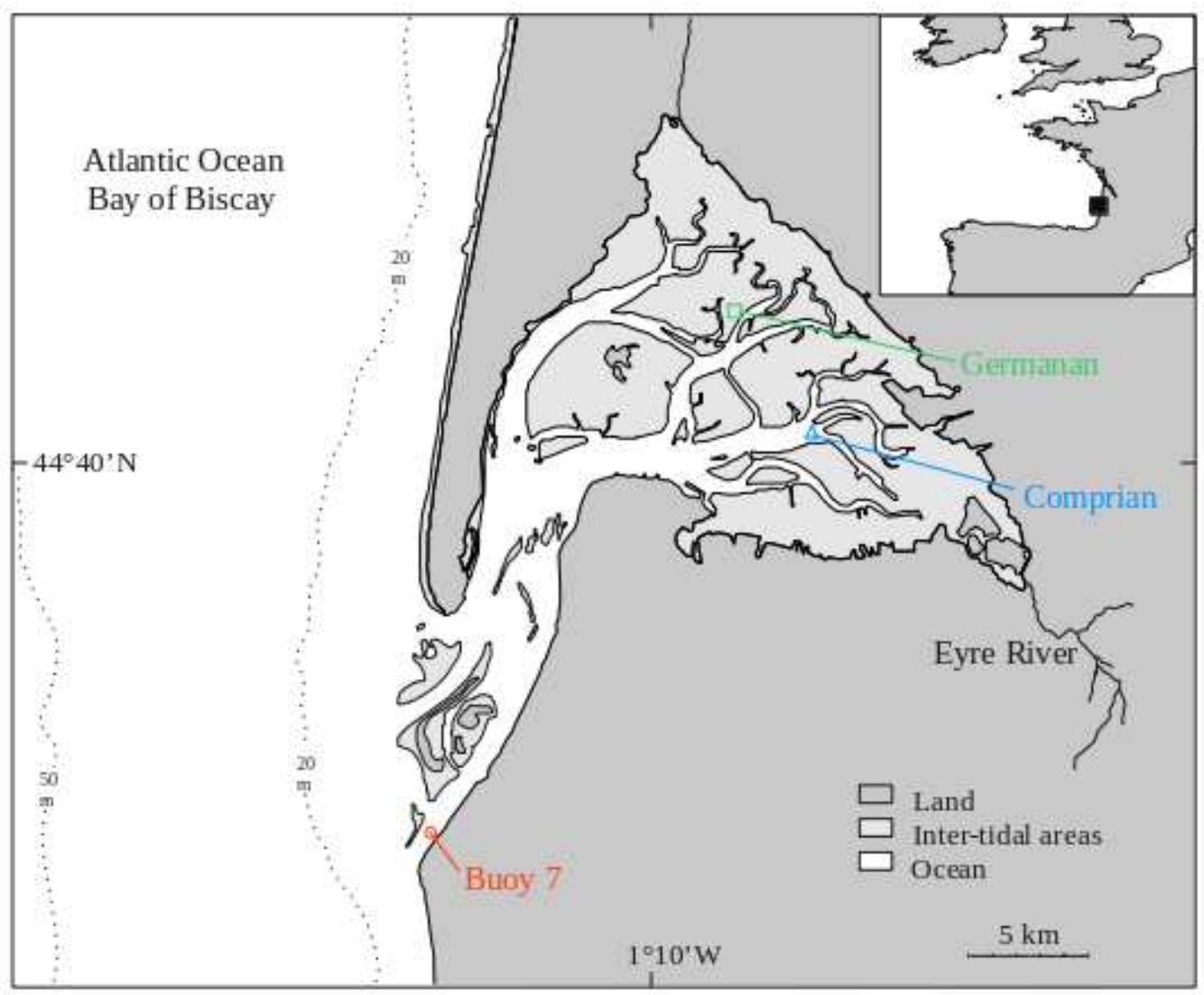

Figure 1. 


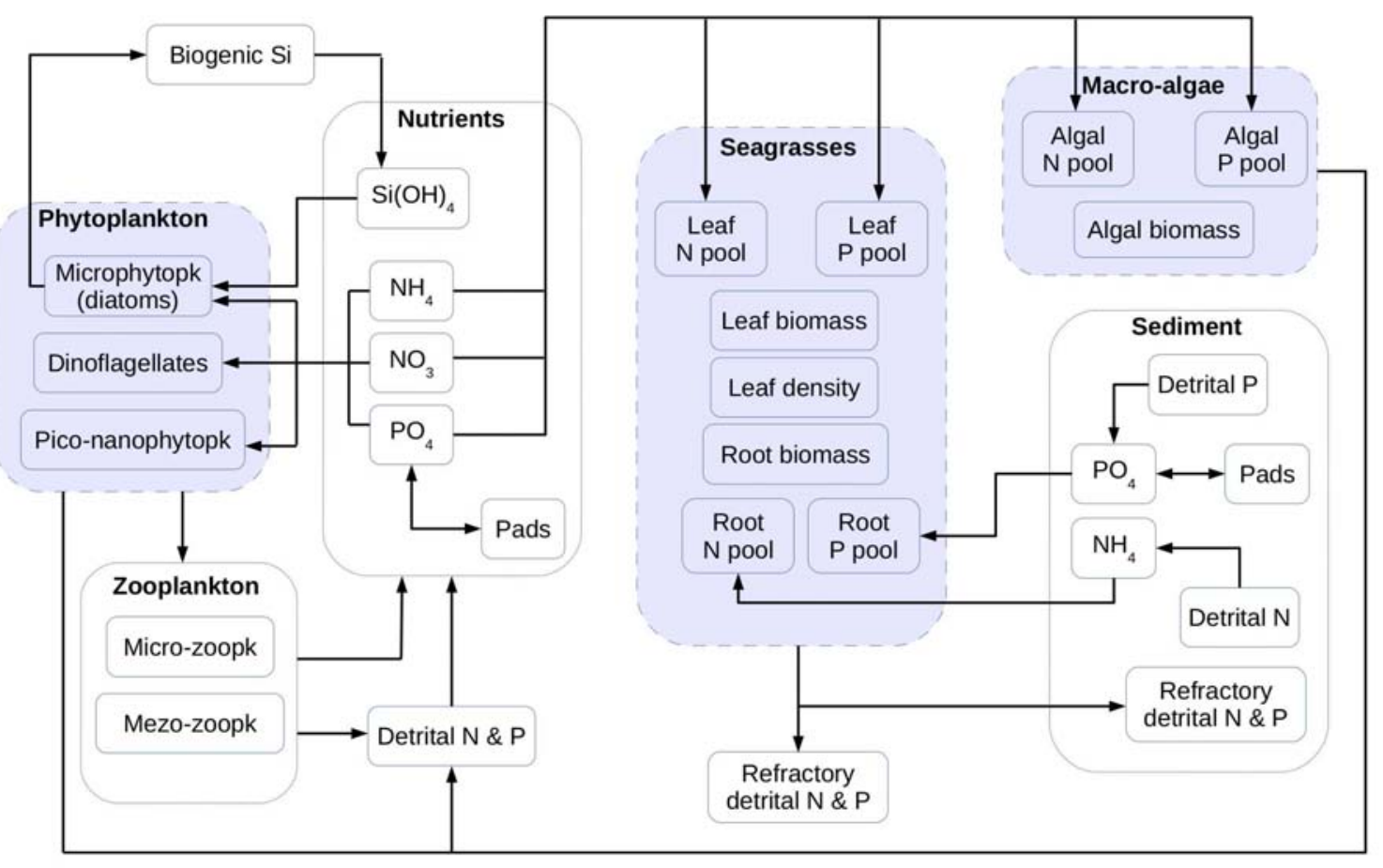

Figure 2. 

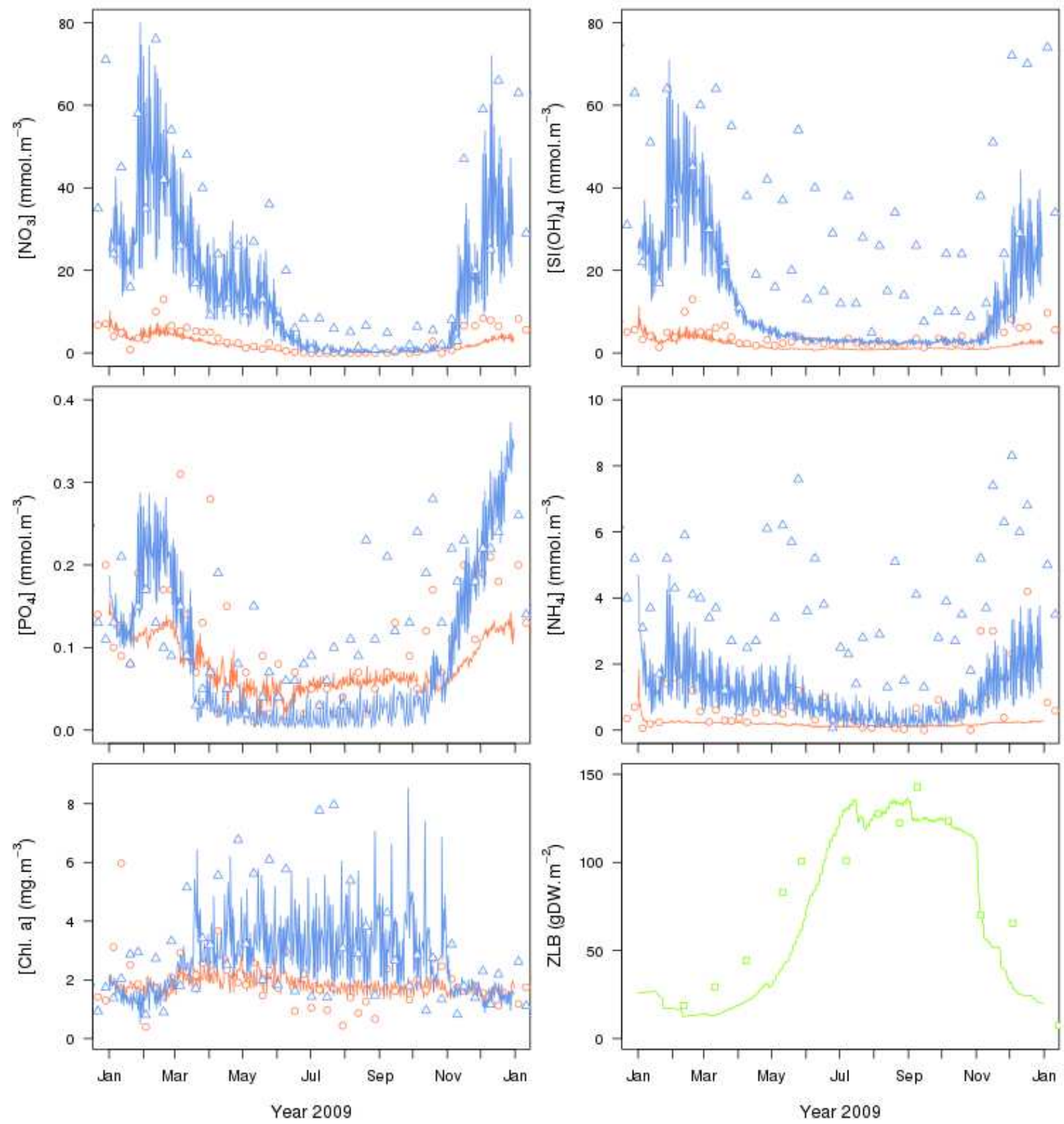

Figure 3. 


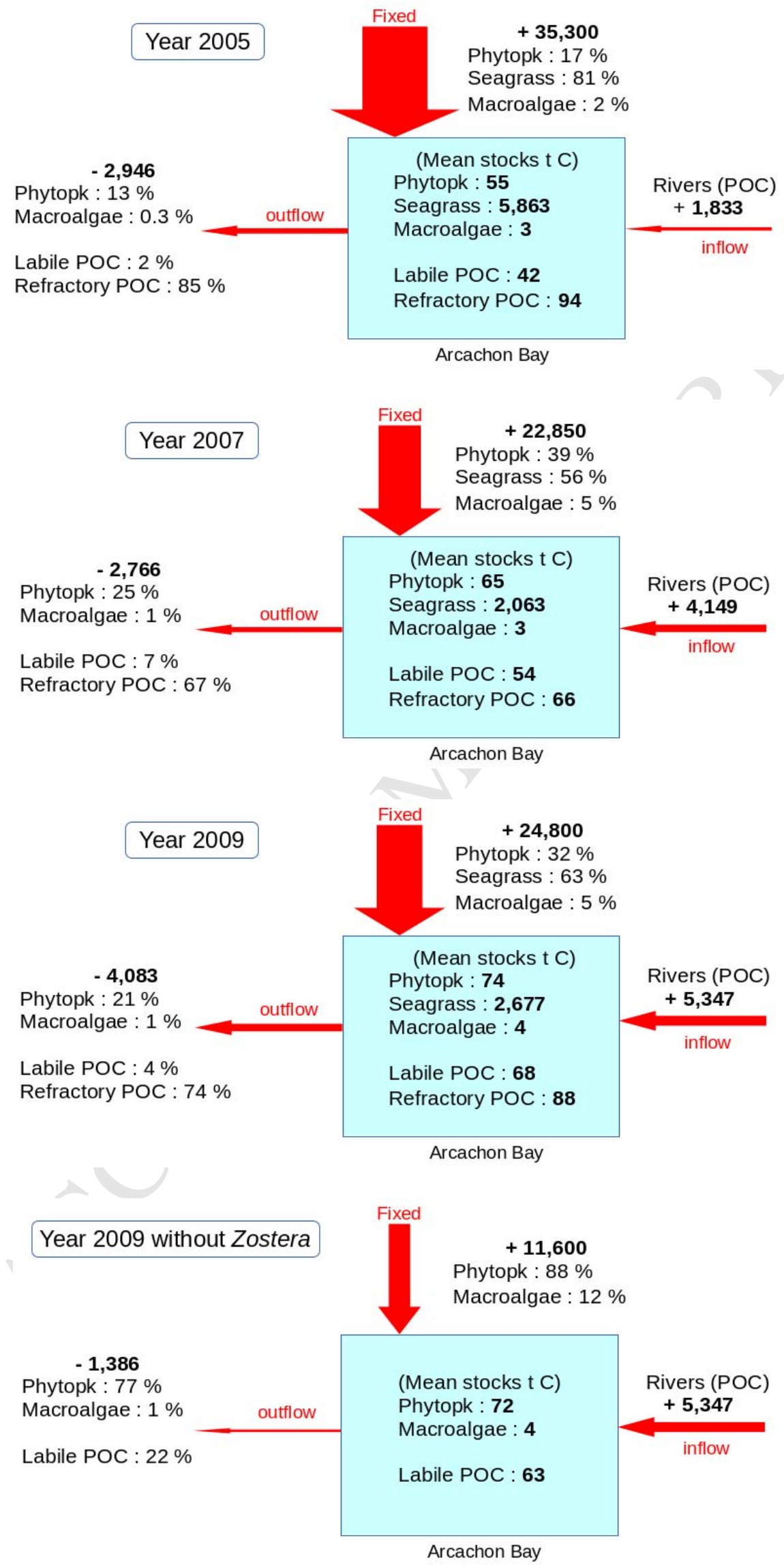

Figure 4. 